\title{
ACCOUNTANTSVERKLARINGEN BIJ ONDERNEMINGEN DIE IN INDONESIË WERKZAAM ZIJN
}

\author{
door P. J. H. J. Bos
}

In februari 1959 is door de C.A.B. aan het bestuur van het N.I.v.A. een advies over voornoemd onderwerp uitgebracht, welk advies is gepubliceerd in „De Accountant", 65e jaargang no. 7.

In het oktober-nummer, jaargang 1959 van het M.A.B., heeft collega Frielink hierop gereageerd. Hoewel hij met de karakterisering van de situatie, zoals de C.A.B. die geeft, accoord kan gaan en waardering uitspreekt voor de analyse, die de C.A.B. laat volgen t.a.v. de invloed, die de wijziging van omstandigheden op de mogelijkheid tot het geven van een verklaring omtrent de jaarrekening heeft, kan hij zich met de consequenties die de C.A.B. aan deze analyse verbindt, niet verenigen. Naar zijn mening zijn die consequenties te formalistisch bezien, niet op de realiteit afgestemd en kunnen deze leiden tot hypocritische formuleringen.

De beantwoording van de vraag of deze verwijten juist zijn, laat ik aan de lezers van dit maandblad over. Daar zij de discussie niet ten goede komen, volsta ik met in te gaan op het meningsverschil, zoals dit in de door de C.A.B. resp. door collega Frielink voorgestelde verklaringen tot uitdrukking komt.

De C.A.B. geeft in overweging om, ingeval het niet voor beoordeling vatbare Indonesische belang relatief groot is en daartegenover geen voorzieningen van een ongeveer evengroot bedrag zijn getroffen, een ,mededeling" van de accountant van de volgende strekking in het jaarverslag te doen opnemen:

„dat hij zich er van overtuigd heeft dat de activa en passiva, voorzover deze behoren tot het bedrijfsdeel buiten Indonesië, in de balans zijn opgenomen en dat hij zich met de waardering ervan kan verenigen;

dat hij de winst- en verliesrekening, die uitsluitend betrekking heeft op het beheer buiten Indonesië, heeft gecontroleerd en accoord bevonden.

„dat hij bij de jaarrekening geen goedkeurende verklaring kan geven, omdat de waardering van het belang in Indonesië zich aan zijn beoordeling onttrekt".

Collega Frielink ontwikkelt hiertegen een aantal bezwaren en stelt, dat ook in het door de C.A.B. genoemde geval een „schone” verklaring kan worden afgegeven, mits het directieverslag over een en ander voldoende uitsluitsel geeft. Wil men voorzichtigheidshalve in de verklaring een aanwijzing omtrent de onzekerheid hebben, dan ware deze z.i. als volgt te formuleren:

„Nagezien en accoord bevonden, onder aantekening dat het belang in Indonesië wegens de daaromtrent heersende onzekerheid, is gewaardeerd op dezelfde wijze als op de vorige jaarrekening".

Collega Frielink stelt, dat het propageren van verklaringen, die noch goedkeurend noch afkeurend zijn, de waardering van het maatschappelijk verkeer voor de accountantsarbeid niet zal doen toenemen.

Ook naar mijn mening wordt de behoefte van het maatschappelijk verkeer aan het oordeel van een onafhankelijke deskundige m.b.t. de gepubliceerde jaarrekening alleen vervuld indien een goedkeurende verklaring wordt afgegeven. Het opnemen van een afkeurende verklaring heeft in het algemeen geen zin, tenzij kan 
worden aangegeven hoe naar de mening van de accountant de jaarrekening wel moet luiden.

De C.A.B. heeft in het verleden eveneens als norm gesteld, dat het opnemen van een niet goedkeurende verklaring in een gepubliceerd jaarverslag geen zin heeft, daar deze niet goedkeurende verklaring betekent, dat de accountant, zij het ook veelal door omstandigheden buiten zijn wil en die van de opdrachtgever, geen oordeel heeft. De C.A.B. is dus consequent als zij stelt dat, wanneer de relatieve grootte van de balanspost, betrekking hebbende op het belang in Indonesië, het maken van een voorbehoud uitsluit, geen goedkeurende verklaring met betrekking tot de jaarrekening kan worden afgegeven. Een dergelijke goedkeurende verklaring houdt toch altijd in, dat naar het oordeel van de accountant de jaarrekening een juist beeld geeft van de grootte, de samenstelling en de aanwending van het aan de onderneming ter beschikking staande vermogen, alsmede van de winst, terwijl een voorbehoud aan de strekking van deze verklaring geen afbreuk mag doen.

Indien de accountant, die gedurende enkele jaren een goedkeurende verklaring heeft afgegeven, het gewenst vindt de reden te vermelden, dat hij voor het desbetreffende verslagjaar geen goedkeurende verklaring kan afgeven, is dit echter geen verklaring, doch een mededeling; een oordeel wordt juist niet kenbaar gemaakt.

Hiermede is m.i. de vraag van collega Frielink beantwoord, waarom de C.A.B. consequent spreekt van een mededeling i.p.v. een verklaring. Daar in de laatste alinea van de door de C.A.B. voorgestelde mededeling uitdrukkelijk gesteld wordt dat geen goedkeurende verklaring omtrent de jaarrekening kan worden gegeven, kan een terzake deskundige lezer hieruit nooit afleiden, dat een goedkeurende verklaring met een voorbehoud wordt gegeven en dan nog wel in strijd met art. 11, lid 1 R.v.A.

Wanneer men met de C.A.B. van mening is, dat in casu geen goedkeurende verklaring omtrent de jaarrekening kan worden afgegeven, rijst de vraag of er wel plaats is voor een mededeling door de accountant, resp. een anders gerichte verklaring; in de formulering van de C.A.B. gaat aan de negatieve mededeling, dat de accountant geen oordeel heeft over de jaarrekening, een positieve mededeling (verklaring) vooraf, als onder nader omschreven.

Collega Frielink stelt onder punt 4, dat de door de C.A.B. voorgestelde mededeling in zichzelf strijdig is. Dit is echter alleen maar het geval als zijn interpretatie wordt gevolgd. In de hiervoor weergegeven gedachtengang wordt door de C.A.B. verklaard, dat a. (het verslag over het gevoerde beheer) accoord is bevonden, doch wordt met betrekking tot $\mathrm{b}$ (de jaarrekening) medegedeeld dat geen goedkeurende verklaring kan worden gegeven omtrent de jaarrekening.

In het voorgaande is reeds vermeld, dat als norm moet worden gesteld, dat het opnemen in een gepubliceerd verslag van een niet goedkeurende verklaring geen zin heeft. In het algemeen is het voorts ongewenst aan de mededeling dat geen goedkeurende verklaring kan worden afgegeven, (onder opgave van de reden) een omschrijving te doen voorafgaan van wat wel accoord werd bevonden. In het kader van de gebruikelijke doelstelling van de opdracht, namelijk een oordeel omtrent de jaarrekening, zou dit tot misverstand aanleiding kunnen geven.

Een norm is echter geen dogma, doch is, zoals door Prof. Limperg is gesteld, alleen bedoeld als richtsnoer, hetwelk het mogelijk maakt in de oneindige verscheidenheid van de bijzonderheden der praktijk de koers te houden. De C.A.B. 
heeft dan ook m.i. terecht nagegaan of in dit bijzondere geval de norm zonder meer kan worden toegepast. $\mathrm{Zij}$ heeft hierbij overwogen dat in de rationele behoefte van het maatschappelijk verkeer aan het oordeel betreffende de jaarrekening om de hiervoor aangegeven reden niet kan worden voldaan. Ik wil hieraan toevoegen, dat een goedkeurende accountantsverklaring bij de jaarrekening in een geval, waarin ieder weet dat door omstandigheden de betekenis, welke voor de onderneming aan relatief grote belangen in Indonesië nog kan worden gehecht, niet kan worden bepaald, en het eigen vermogen dus niet kan worden overzien, de waardering van het maatschappelijk verkeer voor de accountantsarbeid zeker niet zal doen toenemen. Een verklaring omtrent de jaarrekening heeft nu eenmaal een vaststaande inhoud, waaraan men niet kan voorbijgaan.

De C.A.B. heeft klaarblijkelijk echter mede overwogen, dat het belang in Indonesië in feite buiten het normale bedrijfsgebeuren is komen te staan, terwijl in Indonesië door de verantwoordelijke leiding der onderneming geen bedrijfshandelingen meer geschieden; de accountant kan zich voorts wel een oordeel vormen t.a.v. de vraag of de jaarrekening een juist verslag geeft over het gevoerde beheer van het vermogen buiten Indonesië en een juist beeld van het behaalde resultaat met betrekking tot de bedrijfsuitoefening buiten Indonesië. Hier ligt nu mede een rationele behoefte van het verkeer en het zou m.i. zuiver formalisme zijn te stellen, dat, nu onder de gegeven omstandigheden geen goedkeurende verklaring m.b.t. de jaarrekening kan worden afgelegd, ook in de rationele behoefte van het maatschappelijk verkeer aan een oordeel van de accountant of de jaarrekening een juist verslag geeft van het gevoerde beheer en een juist beeld van het behaalde resultaat t.z.v. bedrijfsuitoefening buiten Nederland, niet kan worden voorzien.

De opmerking, dat niet de waardering doch de juistheid daarvan zich aan het oordeel van de accountant onttrekt is m.i. voor het onderhavige vraagstuk van geen belang. In feite is er trouwens geen waardering geschied en kan deze ook niet geschieden. Dat een balansbedrag is vastgesteld (hetzij op hetzelfde bedrag als het vorige jaar hetzij als stelpost) is geen waardering; waardering is toch een economisch begrip. Overigens dreigt dit een woordenspel te worden.

$\mathrm{Na}$ het voorgaande, waarin ik getracht heb aan te tonen, dat de critiek van collega Frielink onjuist is, wanneer men zich op het standpunt stelt, dat een goedkeurende verklaring bij de jaarrekening in de gestelde casus-positie niet mogelijk is, blijft te onderzoeken of de argumenten, die collega Frielink aanvoert voor zijn stelling, dat een ,schone verklaring" mogelijk is, overtuigend zijn.

Een bewijs putten uit analogie is altijd een gevaarlijk werk en zelden overtuigend. In casu is de verwijzing naar de bestaande onzekerheden bij de waardering van de in het artikel genoemde actiefposten m.i. onjuist. Indien deze onzekerheid van dezelfde orde is als in het door de C.A.B. gestelde geval, zou een goedkeurende verklaring van de accountant, die toch mede inhoudt, dat de jaarrekening een juist beeld geeft van de financiële positie, onwaarachtig worden.

Het zou mij overigens te ver voeren op de waardering van de genoemde actiefposten, waaronder immateriële activa, in te gaan. Dat de waardering van deze activa op de balans van een going-concern zich veelal aan het oordeel van de accountant onttrekt, onderschrijf ik niet. De accountant heeft wel degelijk een bedrijfseconomisch oordeel over het bij de waardering gevolgde systeem. Bij een going-concern, waarbij geen activa buiten het bedrijfsgebeuren staan, dienen de twee groepen van gegevens, die de jaarrekening verschaft $\mathrm{nl}$. die betreffende de kapitaals- en ver- 
mogenscompenenten en die betreffende het behaalde resultaat, in onderling verband te worden beschouwd en blijven de genoemde onzekerheden nagenoeg altijd binnen de grenzen, waarbinnen kan worden gesteld, dat de opeenvolgende jaarrekeningen voldoende inzicht geven voor de belanghebbenden. Indien in een concreet geval de onzekerheid t.a.v. één of meer actiefposten van die aard wordt, dat de beoordeling van de financiële positie van de onderneming hierdoor onmogelijk wordt, zal de accountant geen goedkeurende verklaring kunnen geven.

Het argument, dat de toelichting in het directieverslag de grondslagen voor de waardering vermeldt en ieder terzake deskundig weet, dat voor dergelijke activa geen objectief juiste waardering geldt, doet wel overtuigend aan doch is het niet.

Van de accountant wordt verwacht, dat hij het systeem van waardering toetst aan de bedrijfseconomische grondslagen, die hij juist acht. In casu kan de directie in het verslag alleen mededelen, dat zij niet kan overzien of terzake van de belangen in Indonesië vergoedingen zullen worden ontvangen en zo ja welk bedrag. Zomin als de accountant een goedkeurende verklaring kan geven bij een jaarrekening, die hij niet juist vindt, op grond van het feit, dat de correctie in het jaarverslag is aangegeven, zomin kan m.i. een accountant als hij over een relatief belangrijke balanspost geen oordeel heeft, een goedkeurende verklaring afgeven op grond van het feit, dat de directie heeft vermeld, dat zij evenmin een oordeel heeft, maar voorlopig de oude boekwaarde heeft aangehouden.

De door collega Frielink vastgestelde formulering, $\mathrm{nl}$.

„Nagezien en accoord bevonden onder aantekening dat het belang in Indonesië wegens daaromtrent heersende onzekerheid is gewaardeerd op dezelfde wijze als op de vorige jaarrekening",

is m.i. in strijd met het reglement van arbeid (art. 16 lid 2 en art. 11 lid 2). Hier betreft het toch een goedkeurende verklaring omtrent de jaarrekening en heeft de aantekening in feite geen andere strekking dan een voorbehoud.

Wanneer ondanks de geheel gewijzigde omstandigheden toch dezelfde waardering als op de vorige jaarrekening wordt aangehouden en de accountant evenmin als de directie kan beoordelen, welke gevolgen de gewijzigde omstandigheden voor de onderneming zullen hebben, is, indien het om een relatief groot belang gaat, de voorgestelde verklaring m.i. alleen formeel waar en wordt voorbij gegaan aan de realiteit, dat de financiële positie der onderneming niet kan worden overzien.

Mijn persoonlijke mening is dan ook, dat de door de C.A.B. voorgestelde formulering wel op de realiteit is afgestemd. Enerzijds wordt een positieve mededeling gedaan die voorziet in een rationele behoefte van het maatschappelijk verkeer die wel vervuld kan worden en anderzijds geeft zij duidelijk aan, waarom de behoefte van het maatschappelijk verkeer aan een oordeel omtrent de jaarrekening niet vervuld kan worden door omstandigheden, onafhankelijk van de wil van de accountant en van de directie; deze omstandigheden zijn ieder bekend. De ,,mededeling" van de C.A.B. kan m.i. niet tot misverstand aanleiding geven en is voor ieder duidelijk. Niemand kan het voorts vreemd vinden, dat de accountant onder de gegeven omstandigheden geen goedkeurende verklaring afgeeft $\mathrm{m}$.b.t. de jaarrekening. De formulering van collega Frielink gaat voorbij aan het feit, dat de goedkeurende verklaring bij een jaarrekening los van de gekozen formulering een vaststaande inhoud heeft verkregen. 
Wanneer, zoals in casu het geval is, m.b.t. een actiefpost, waarvoor op de balans een relatief belangrijk bedrag is opgevoerd, ernstig rekening moet worden gehouden met de mogelijkheid - zij het ook door handelingen van derden die ons rechtsgevoel niet bevredigen - dat dit actief geheel verioren is resp. gaat en het dubieus is of er een en zo ja welke vergoeding zal worden ontvangen, zal ook de accountant de realiteit onder ogen moeten zien en daaruit de consequenties moeten trekken t.a.v. zijn verklaring omtrent de jaarrekening. De formele oplossing om in de verklaring een aantekening op te nemen, dat het belang wegens daaromtrent heersende onzekerheid is gewaardeerd op dezelfde wijze als op de vorige jaarrekening, is m.i. onbevredigend en ongewenst. De strekking van de aantekening is toch, dat aan het bijzondere van de casus-positie, daarin bestaande, dat de financiële positie der onderneming niet kan worden aangegeven, zolang niet bekend is tot welk bedrag de balanswaarde van het belang in Indonesië te hoog is, geen enkele consequentie wordt verbonden met betrekking tot de verklaring. Waarom zullen wij trachten door middel van niet terzake doende vergelijkingen aan deze waarheid voorbij te gaan en de consequenties t.a.v. onze verklaring te ontgaan? 